\title{
Zelfreflectie
}

\section{Irritatie als toeterende sirene}

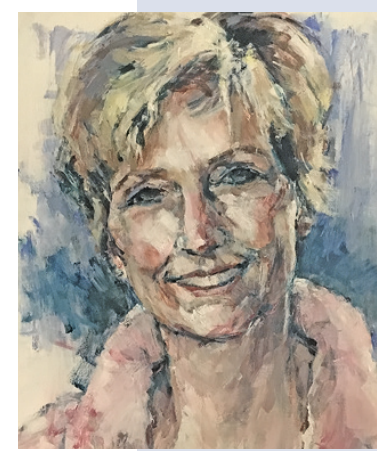

\section{Anita Kaemingk}

Voelt u wel eens ergernis opborrelen als het over uw werk gaat? En weet u dan waarom? Bij mij gebeurt dat blijkbaar bij bepaald zorgjargon in de spreekkamer. Hoe reageer je bijvoorbeeld het beste als een patiënt vertelt dat vader nog maar 53 jaar was toen hij plotseling overleed, en o ja, zus was ook zo jong? Deze kwestie kwam aan de orde tijdens een nabespreking van het simulatiepatiëntencontact bij tweedejaars geneeskundestudenten.

Een student opperde: "Hoe is dat voor u?" "Nah, beetje irritant", zei ik, duidelijk iets te snel.

"Wat doet dat met u?", riep een andere student. "Brrr", zei ik, en de rillingen liepen over mijn rug.

In mijn ogen gaat het hier om onechte leerboekformuleringen die de patiënt moeten aansporen zich kwetsbaar op te stellen tegenover iemand die daar overduidelijk nauwelijks in geïnteresseerd is. Daar heb ik moeite mee. In dit soort situaties denk ik graag aan mijn overleden schoonmoeder. Zij had geen moeite met zich kwetsbaar opstellen. Zou zij deze vragen wel prettig hebben gevonden? Bij mij appelleren ze blijkbaar aan iets wat ik niet graag doe, of niet goed kan.

Andere zorgprofessionals hebben andere ergernissen. "Irritant stukje", schreef een gepensioneerde huisarts naar aanleiding van een column over mijn huisartsenswitch. Doornen in zijn oog waren vooral de vraag van mijn oncoloog of ik goed contact had met mijn huisarts (waarom zou dat niet zo zijn?) en het feit dat de huisarts van mijn partner op huisbezoek kwam nadat hij van mijn slechte prognose gehoord had (wat moest die man bij de patiënt van een ander?). Mijn stukje had blijkbaar geappelleerd aan een belangrijk, wellicht onbewust, aspect in zijn werkende leven, iets wat hij niet graag deed of niet goed kon. Waar ik de monitorfunctie van beide artsen waardeerde, zeker ook de aandacht voor mijn partner, was dit voor hem blijkbaar een brug te ver.
Irritatie is een hinderlijke (inderdaad irritante) emotie waarvan we de verantwoordelijkheid het liefst uitbesteden, het ligt altijd aan de ander. Dat is jammer, want die externalisatiereflex leidt doorgaans niet tot bevredigende oplossingen, terwijl die ons wel afhoudt van de speurtocht naar wat er werkelijk aan de hand is. Irritatie zegt soms wel iets over de ander, maar doorgaans meer over onszelf. Ze spiegelt onze persoonlijke allergieën of blinde vlekken. Voor een zorgprofessional is het goed om hier even bij stil te staan, want je zou zomaar een patiënt kunnen benadelen.

Dat gebeurde bij de bedrijfsarts van een kennis. "Hij was duidelijk geïrriteerd", zegt ze. Ze beschrijft de eerste keer dat ze op zijn spreekuur kwam en kon vertellen dat het aanzienlijk beter met haar ging dankzij het goede werk van zijn collega. Fijne inhoudelijke gesprekken en duidelijke steun hadden haar weer enigszins op de rails gekregen na een burn-out.

"O, die", had hij geschamperd waarna hij driftig op zijn toetsenbord hamerde en vroeg wanneer ze weer aan het werk zou gaan. "Maar was hij dan niet blij dat je zo vooruit ging?", vraag ik verbaasd. "Nee, die man is helemaal niet geïnteresseerd in mijn herstel”, zegt ze, "zijn prioriteiten liggen bij regels uitvoeren en de baas tevreden houden." Door zijn gepush duurde het onnodig lang voor ze met een beetje vertrouwen weer aan het werk was.

Een bedrijfsarts die zich wrevelig verschuilt achter 'bijzaken', voor een arts dan toch, en het herstel van zijn patiënt in de weg zit? Appelleerde het succes van zijn collega aan zijn eigen beperkingen, was hij jaloers op haar succesvolle gesprekstechnieken? Soms is irritatie niet zomaar een signaal, maar een toeterende sirene.

Voelt u zich nu iets geprikkeld? Mooi, dan hebt u meteen oefenstof voor introspectie. 